\title{
Environmental Conditions of Settlement of the Danubian Communities in the Northern Foreland of the Sandomierz Upland
}

\author{
Marcin Szeliga ${ }^{a}$, Radosław Dobrowolski ${ }^{b}$, Przemysław Mroczek ${ }^{c}$, \\ Jacek Chodorowski ${ }^{d}$, Irena Agnieszka Pidek ${ }^{e}$, Daniel Makowiecki ${ }^{f}$ \\ and Maria Lityńska-Zając ${ }^{g}$
}

\begin{abstract}
The article raises the issue of the nature, intensity and environmental conditions of the settlement processes occurring on the borderline of the loessic Sandomierz Upland and the sandyclay areas of the Ilża Foothills, between the end of the 6th and the beginning of the 4th millennia BC. The results of previously conducted research confirm the high settlement activity in these areas, throughout the period of development of the Danubian cultural groups. The obtained data document the phenomenon of the formation and functioning of the early-agricultural settlement centres in upland areas, located outside the range of compact loess cover, i.e. within ecological and landscape zones that diverge from the basic preferences of the Danubian communities, inhabiting the upland areas of the upper Vistula basin.
\end{abstract}

KEY-WORDS: Neolithic, Danubian communities, settlement, marginal zone of loess cover, natural environment

a Institute of Archaeology, Maria Curie-Skłodowska University in Lublin, 4. M. C.-Skłodowska sq., 20-03I Lublin, Poland, e-mail: marcin.szeliga@poczta.umcs.lublin.pl ORCID: 0000-0002-5185-073X

${ }^{b}$ Institute of Earth and Environmental Sciences, Maria Curie-Skłodowska University in Lublin, 2d Kraśnicka av., 20-718 Lublin, Poland, e-mail: rdobro@poczta.umcs.lublin.pl ORCID: 0000-0002-6504-5643 Institute of Earth and Environmental Sciences, Maria Curie-Skłodowska University in Lublin, 2d Kraśnicka av., 20-7I8 Lublin, Poland, e-mail: loess@poczta.umcs.lublin.pl ORCID: 0000-0003-2702-5577

${ }^{d}$ Institute of Earth and Environmental Sciences, Maria Curie-Skłodowska University in Lublin, 2d Kraśnicka av., 20-7I8 Lublin, Poland, e-mail: jchodor@poczta.umcs.lublin.pl ORCID: 0000-0003-II34-9526

Institute of Earth and Environmental Sciences, Maria Curie-Skłodowska University in Lublin, 2d Kraśnicka av., 20-718 Lublin, Poland, e-mail: i.pidek@poczta.umcs.lublin.pl ORCID: 0000-0002-I979-4897

$f$ Institute of Archaeology, Nicolaus Copernicus University in Toruń, 44/48 Szosa Bydgoska st., 87-Ioo Toruń, Poland, e-mail: Daniel.Makowiecki@umk.pl ORCID: 00oo-0002-I82I-4627

$g$ Institute of Archeology and Ethnology, Polish Academy of Sciences, I7 Sławkowska st., 3I-OI6 Kraków, Poland, e-mail: marialitynska@gazeta.pl ORCID: oooo-0002-6397-9805 
2 | Marcin Szeliga, Radostaw Dobrowolski, Przemystaw Mroczek, Jacek Chodorowski ...

\section{INTRODUCTION}

The Sandomierz Upland is one of the most cognitively important regions for studies on the sequence, nature and dynamics of cultural changes, taking place in the Neolithic area within the broadly defined northern foreland of the Carpathians and neighbouring areas. Its geomorphological, hydrological and - especially - soil characteristics, resulting from the presence of a fertile soil cover, formed on a loess ground, as well as close proximity to the abundant deposits of various siliceous rocks, located within the Mesozoic north-eastern slopes of the Świętokrzyskie Mountains, were among the most important factors determining the very high intensity of settlement of agricultural communities between the 6th and $3 \mathrm{rd}$ millennia $\mathrm{BC}$. This also applies to the early phase of this period, related to the development of the Danubian communities, in terms of taxonomy identified with the Linear Pottery culture (LBK), the Malice culture (MLC), the Samborzec-Opatów group (S-OG) and the Lublin-Volhynian culture (L-VC). Although the results of previous research indicate a fundamental relationship between the settlement of these communities and the Sandomierz Upland loess cover, the latest data confirm their significant settlement activity also in the area of its northern edge, especially in a different ecological and landscape zone, covering its northern foreland. Currently, from a very small section of this borderland, extending from Ćmielów (Ostrowiec Świętokrzyski district) to Ożarów (Opatów district), as many as 49 sites, related to the Danubian chronological and cultural horizon, are known (Fig. IC). They significantly supplement the current level of knowledge of the settlement preferences, and - at the same time - the capabilities for adaptation of the early-agricultural communities in the broadly defined "Sandomierz settlement region".

\section{STATE OF RESEARCH}

In the light of the current state of research, the main area of the settlement activity of the Danubian communities covered mainly the central and eastern part of the Sandomierz Upland (Czekaj-Zastawny 2008; Kowalewska-Marszałek 20I2: Fig. 4-5). This is confirmed by the results of previous excavations (e.g. Podkowińska 1959; Więckowska 1971; Michalak-Ścibior and Taras 1995; Kulczycka-Leciejewiczowa 2008; Kowalewska-Marszałek 2017), as well as numerous diagnostic surface finds (MichalakŚcibior 1992: Fig. 2; Kowalewska-Marszałek 2002: 179-185; 2008: 248-253). Until recently, distinct differences in this regard were found in the areas located within this mesoregion's northern edge, especially its foreland - part of the Iłża Foothills (Kondracki 2002: Fig. 38; Fig. IA-B). Relics of the settlement of Danubian communities in these areas were represented only by a few less characteristic findings, found mainly in the loess plateau edge zone (Podkowińska 1952: table XVIII: 4). From the 
neighbouring sandy-clay areas of the Iłża Foothills, only a few single sites were known, indicating the occasional exploitation of local flint outcrops (see e.g. Balcer and Kowalski 1978: I32; Libera and Zakościelna 1990: 62; Budziszewski 1991: 60), rather than permanent settlement on these areas. This situation indicated the clearly different nature of the activities of the Danubian communities in both areas, and showed the link between their stable settlement and the loess cover of the Sandomierz Upland. This corresponded well to the previous arrangements, regarding the settlement preferences of the Danubian cultural circle (e.g. Modderman 1959: 3-6; Sielmann I971: 80-I24; Končelová 20I2), including the clusters occupying the upper Vistula basin (Kruk 1973: 72-74; Kruk et al. 1996: 4I-48; Czekaj-Zastawny 2008: 98-I04).

New, important data were provided by the results of excavations on site 2 in Ćmielów, Ostrowiec Świętokrzyski district (Michalak-Ścibior 1994), as well as on sites 6 and 12 in Tominy, Opatów district (Szeliga and Zakościelna 2007; Szeliga 2008; Kadrow and Olejarczyk 2oro), located outside the edge of the loess plateau, in the southern part of the Iłża Foothills (Fig. IC and 2A-B). They confirmed the functioning of the early-agricultural single settlements within this unusual, non-loess ecological and landscape zone, starting from the oldest Neolithic phase. They have also become the main reason for undertaking the essential interdisciplinary research, focused, on the one hand, on identification of the basis, nature and intensity of the Danubian settlement, as well as the range of their economic activity in the areas discussed here, and on the other hand - on the reconstruction of all environmental conditions and consequences of these processes, in their chronological and cultural contexts.

\section{OBJECTIVES AND METHODS}

The main goal of the presented study is an attempt to preliminarily assess the nature and scale of the settlements of the Danubian cultural circle, as well as the general characteristics of their relationship to the environmental conditions within the edge part of the Sandomierz Upland and the non-loess zone of its northern foreland. The basic reference plane for these considerations are the results of archaeological research conducted in this area between 2014 and 20I8, supplemented by geological, geomorphological and pedological data, as well as archaeobotanical and archeozoological observations. These data, despite being still incomplete, provide the basis for a preliminary, general assessment of the local natural environment potential and the scope of its use by the early agricultural communities. Archaeological research included both systematic surface surveys, as well as excavations on some of the most promising sites. During the surface surveys, the greatest attention was focused on the areas located in the immediate vicinity of the loess plateau, especially along the valleys of the Wyszmontów Stream, Przepaść and Krzczonowianka rivers. Surveys on more 
216 Marcin Szeliga, Radostaw Dobrowolski, Przemystaw Mroczek, Jacek Chodorowski ...
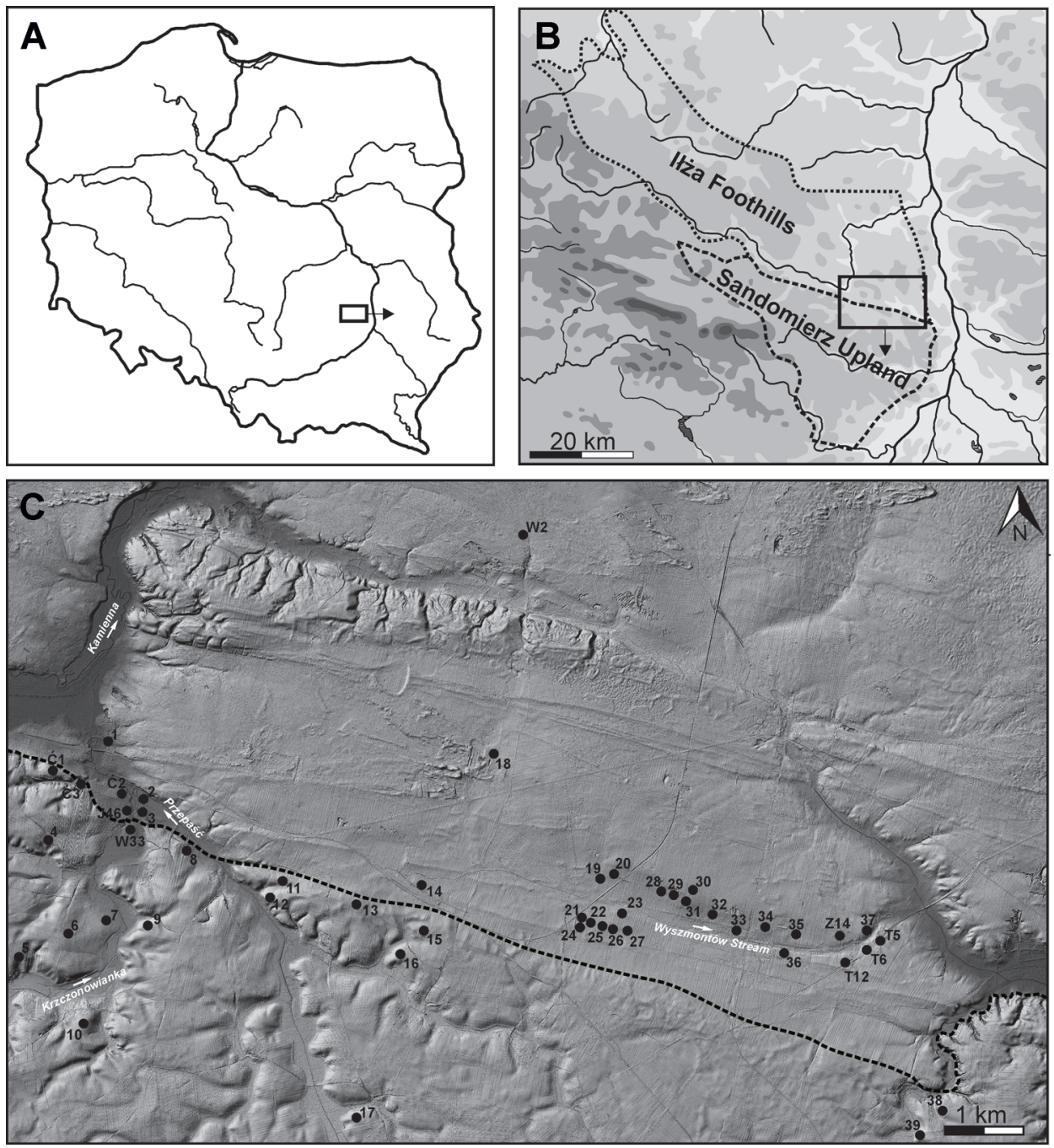

Fig. I. Research area (A-B) with general location of sites related to Danubian cultural circle (C), discovered during surface surveys (numbers) and excavations (letters) within the northern part of Sandomierz Upland and its northern foreland: (B - on the basis of Kondracki 2002, C - range of loess cover by Mroczek 2007, Fig. I). Archaeological sites; excavated: Ć. , 2, 3 - Ćmielów, site. I,2, 95 , Ostrowiec Świętokrzyski district; J46 - Jastków, site 46, Ostrowiec Świętokrzyski district; T5, 6, I2 - Tominy, site 5, 6 i ı2, Opatów district; W2 - Wojciechówka, site 2, Opatów district; W33 - Wólka Wojnowska, site 33, Ostrowiec Świętokrzyski district; ZI4 - Zawada, site I4, Opatów district; Surface surveyed: I - Ćmielów, site. 64 (AZP 85-7I/I90); 2 - Wólka Wojnowska, site 8 (AZP 85-7I/I23); 3 - Wólka Wojnowska, site 5 (AZP 85-7I/I20); 4 - Jastków, site 3I (AZP 85-7I/272); 5 - Glinka, site 4 (AZP 85-7I/I73); 6 - Jastków, site 4I (AZP 85-7I/370); 7- Jastków, site 38 (AZP 85-7I/367); 8 - Wólka 
Wojnowska, site I8 (AZP 85-72/I53); 9 - Wólka Wojnowska, site 26 (AZP 85-7I/24I); IO - Buszkowice, site I8 (AZP 86-7I/I36); II - Drygulec, site I5 (AZP 85-72/IIO); I2 - Drygulec, site I4 (AZP 85-72/I09); I3 - Drygulec, site I8 (AZP 85-72/180); I4 - Ługi, site 3 (AZP 85-72/I79); I5 - Mikułowice, site 4I (AZP

85-72/I8I); I6 - Mikułowice, site Io (AZP 85-72/16); I7 - Wojciechowice, site II (AZP 86-72/54); I8 - Julianów, site I7 (AZP 85-72/182); I9 - Wyszmontów, site 32 (AZP 85-72/54); 20 - Wyszmontów, site

33 (AZP 85-72/55); 2I - Jasice, site 46 (AZP 85-72/185); 22 - Wyszmontów, site 64 (AZP 85-72/184); 23 - Wyszmontów, site 65 (AZP 85-72/187); 24 - Jasice, site 47 (AZP 85-72/186); 25 - Wyszmontów, site 30 (AZP 85-72/51); 26 - Wyszmontów, site 29 (AZP 85-72/50); 27 - Wyszmontów, site 63 (AZP 85-72/183); 28 - Wyszmontów, site 35 (AZP 85-72/57); 29 - Wyszmontów, site 36 (AZP 85-72/58); 30 - Wyszmontów, site 66 (AZP 85-72/I88); 3 I - Wyszmontów, site 37 (AZP 85-72/59); 32 - Wyszmontów, site 4 (AZP 85-73/166); 33 - Wyszmontów, site 5 (AZP 85-73/167); 34 - Wyszmontów, site 3 (AZP 85-73/165); 35 - Wyszmontów, site 60 (AZP 85-73/28I); 36 - Wyszmontów, site 6I (AZP 85-73/282); 37 - Zawada, site 42 (AZP 85-73/2I4); 38 - Jankowice, site II (AZP 86-73/I46); 39 - Bińkowice, site 2 (AZP 86-73/138).

distant areas was only of a verification nature, covering exclusively sites (and their immediate surroundings) related to the Danubian horizon during prior surface surveys of the Polish Archaeological Record Project (Fig. IC).

\section{RESULTS}

\section{Archaeological data}

As a result of the conducted surface surveys, I2 new Danubian circle archaeological sites were discovered, and 37 previously known ones were verified. The vast majority of them are grouped within two basic zones. The western zone includes areas located directly at the junction of the loess cover and sandy-clay deposits, ranging from Ćmielów in the west to Mikułowice and Ługi (Opatów district) in the east (Fig. 2A). They are generally characterized by a significant degree of the dispersion of the settlement remains, with a significant concentration of large settlement sites in a small area along the lower section of Krzczonowianka, near its mouth to the Przepaść River. The eastern zone is located entirely in the non-loess area, at a distance of about 0,5 to I km from the edge of the Sandomierz Upland, extending from Wyszmontów, Opatów district in the west, to Tominy in the east (Fig. 2B). It includes a greater number of settlement remains, represented both by a large sites, as well as numerous trace findings. In comparison to the western zone, they reveal a much larger degree of territorial density, extending along the middle section of the Wyszmontów Stream valley, primarily in the upland range on its northern side, but also within its lower part. Except the mentioned areas of concentration, only two sites related to the Danubian horizon are currently known in the discussed area, represented by an undefined settlement site in Julianów, Opatów district and presumably a seasonal camp related to the exploitation of nearby Chocolate flint outcrops in Wojciechówka, Opatów district (Fig. IC). 
218 Marcin Szeliga, Radostaw Dobrowolski, Przemystaw Mroczek, Jacek Chodorowski ...
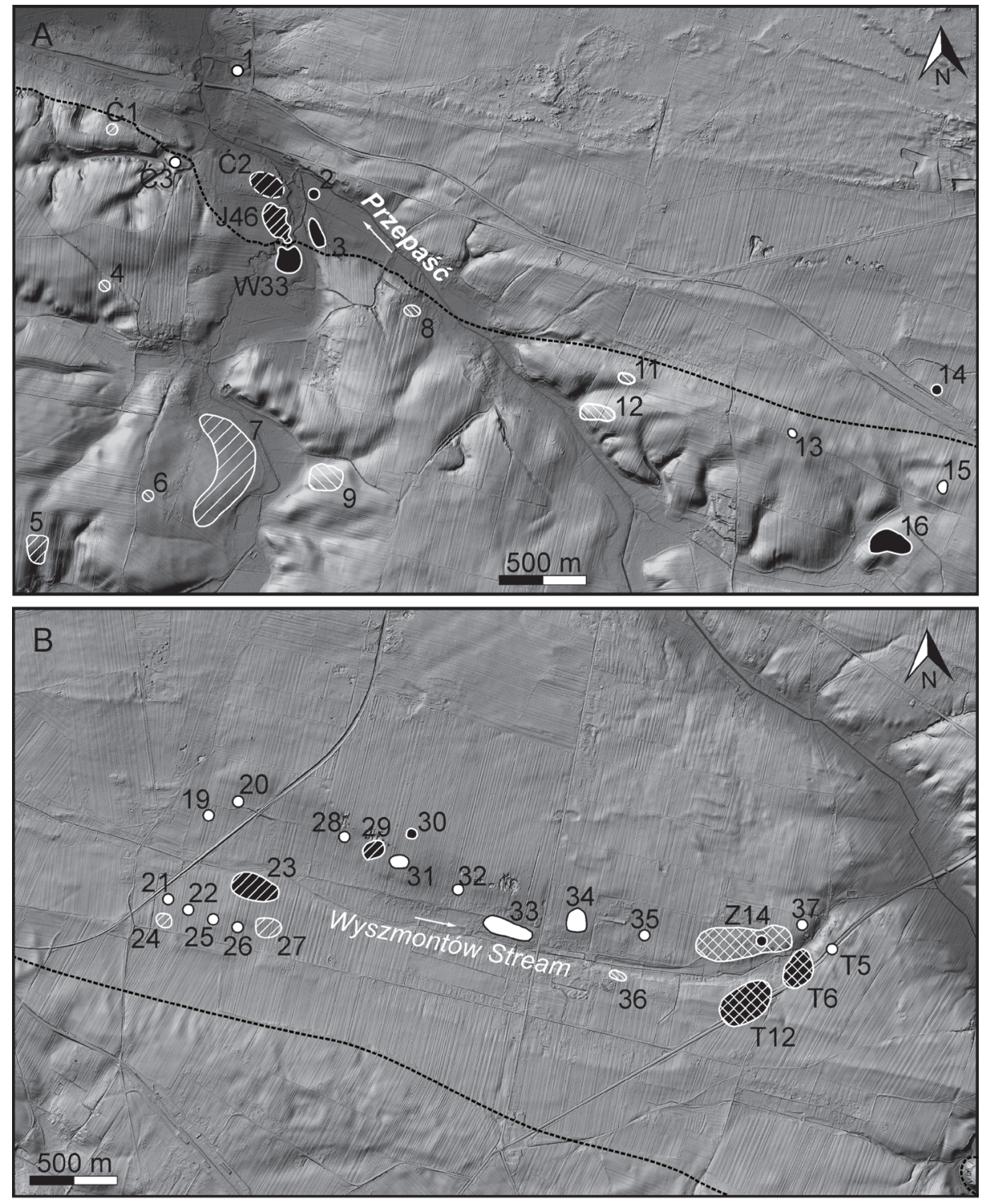

o-a $\diamond-$ - $\square-c \square-d \square-e \square-f, \cdots$

Fig. 2. Location and cultural classification of sites within the western (A) and eastern (B) microregions of settlement of the Danubian communities: a - stray finds; $b$ - settlements; $c$ - Linear Pottery culture; $d$ - Malice culture; $\mathrm{e}$ - Lublin-Volhynian culture; $\mathrm{f}$ - unidentified Danubian circle groups; $\mathrm{g}$ - range of Sandomierz Upland loess cover (by Mroczek 2007: Fig. I).

Designations of sites (numbers and letters); cf. Fig. IC. 
The artefacts obtained in this work enabled the establishment of the chronological and cultural classification of only some of the discovered and verified sites. A total of seven sites were related to the LBK, from which a very few diagnostic ceramic fragments and flint products were collected. They do not reveal any apparent regularities in distribution, occurring in a loose scatter within both separated regions of concentration (Fig. IC).

A more numerous group are sites related to the post-linear horizon, represented by five MLC sites located only within the eastern zone, as well as five L-VC sites, scattered along the whole edge of the Sandomierz Upland (Fig. IC). It is most likely complemented by the majority of the other sites, generally classified as Danubian. Despite the fact that they cannot be precisely related to any culture, the raw materials and morphometric properties of the obtained flint materials, justify their general linkage to the post-linear horizon of the Danubian settlement.

The results of surface surveys are complement by the results of excavation research. In the eastern zone, they included work on the LBK site 6 in Tominy, systematically continued since 2006, as well as a preliminary investigation of the site I4 in Zawada, Opatów district, located on the opposite bank of the Wyszmontów Stream (Fig. IC) and - on the basis of surface findings - related to MLC (Szeliga et al. 2018: I6I, Fig. 2D-E). The acquired data (remnants of archaeological features and rich artefacts) confirmed the existence of permanent and extensive settlements on both sites, related to the late-note and early-Želiezovce LBK phases (Tominy) and the late-classical MLC phase (Zawada). The first radiocarbon dates from Tominy provide a dating of the LBK settlement at least between 5100 and 4800/4700 BC (Szeliga 20I7: 44I). In addition, there was only a small amount of L-VC diagnostic materials on both sites. However, they did not have any firm context in archaeological features, which makes it impossible to assess the nature and scale of the settlement activity of this culture. Similar results were obtained for the western zone, where archaeological excavations started in 2018 were devoted to the preliminary investigation of site 46 in Jastków and site 33 in Wólka Wojnowska, Ostrowiec Świętokrzyski district, where the existence of the LBK settlement of the Želiezovce phase had already been confirmed (Matyaszewski 20I7). Previously collected materials clearly indicate the extensive and permanent nature of both settlements, as well as their occupation on the classical and late phase of the LBK and the classical phase of MLC (Jastków).

\section{Geological and geomorphological setting}

The research area is located on the border of two physical and geographical mesoregions within the northern, marginal part of the Małopolska Upland (Fig. IB). It also lies at the point of contact of two different morphogenetic belts of continental range, loessic and sands (Koster 1988: 69-83). The lithology of the surface sediments exhibit a distinct duality in the latitudinal system. The southern part is called the Sandomierz loess patch, entirely covered by aeolian loess, mainly of Vistulian (=Weichselian) age, 
220 Marcin Szeliga, Radostaw Dobrowolski, Przemystaw Mroczek, Jacek Chodorowski ...

with a thickness of up to $20 \mathrm{~m}$ (Mroczek 2007: Fig. 2). The main feature of the loess cover is its uniform, continuous and compact character, interrupted only by river valleys, within which there are no such deposits (Eanczont et al. 20I4: 30-35). In turn, the surface sediments of the northern part (Iłża Foothills) are characterized by a much more varied, mosaic structure, including Pleistocene sediments of various lithological nature. Also present, though restricted to the bottoms of river valleys, are Holocene alluvial deposits (Fig. 3). The surface exposures of older sediments are mainly glacial tills of the Saalian age, enriched locally with rocky rubble. They build marginal forms within moraine plains, forming strings of isolated, strongly denuded remnant hills. The topmost surface is covered by a relatively thin series of Late Vistulian silicate sands, forming continuous covers, and in some places typical parabolic dunes. They are accompanied by small loess patches with a thickness of a few metres, taking the form of isolated islands and gredas. Their morphological position and spatial orientation emphasize, on the one hand, the diversity of the older topography, and on the other, they indicate the dominant directions of the ancient loess accumulation winds (Fig. 3). The bedrock underlying the Quaternary sediments across the entire area are Jurassic and Upper Cretaceous carbonate rocks, which often appear as outcrops on the surface (Złonkiewicz 1998).

The lithological belt-like duality of this area is reflected in the spatial diversity of the differences in levels and slopes. Their much higher values are typical features of the loess area. This applies first of all to the contact zone of the loess patch with the valleys of Czyżówka River and Kamienna River, which have clearly sublatitudinal course (Fig. IC and 4). Differences in level within the northern part of the Sandomierz loess patch reach up to $30 \mathrm{~m}$ and even $40 \mathrm{~m}$. Generally, this loess patch, characterized by a negligible amount of flat, level surfaces (plateau), is heavily cut with a system of dry erosion-denudational valleys and slope depressions (Fig. 4). In the plateau zone, there are areas of isolated closed depressions (see Maruszczak, I954: I23-I37; I96I: 93-I22). The northern, non-loess part of the studied area is characterized by much smaller relative heights, which only locally increase to $20 \mathrm{~m}$ (Fig. 4). The consequence of this is the relatively small inclination of the slopes, especially marked within the valley zone of two rivers - Wyszmontów Stream and the Przepaść River. The location of the discovered archaeological sites clearly indicates that the gentle slopes and culminations of the small hills that extend along these valleys were particularly preferred as settlement areas by the communities of the Danube groups (Fig. IC and 4).

\section{Soil cover}

The specific lithological types of substrate rocks and the topographic character of the surface affect the different development of the soil cover within both border regions discussed here. The southern part of the research area is characterized by a generally low degree of variation in soil cover, limited to fertile brown soils and lessivè soils (often 


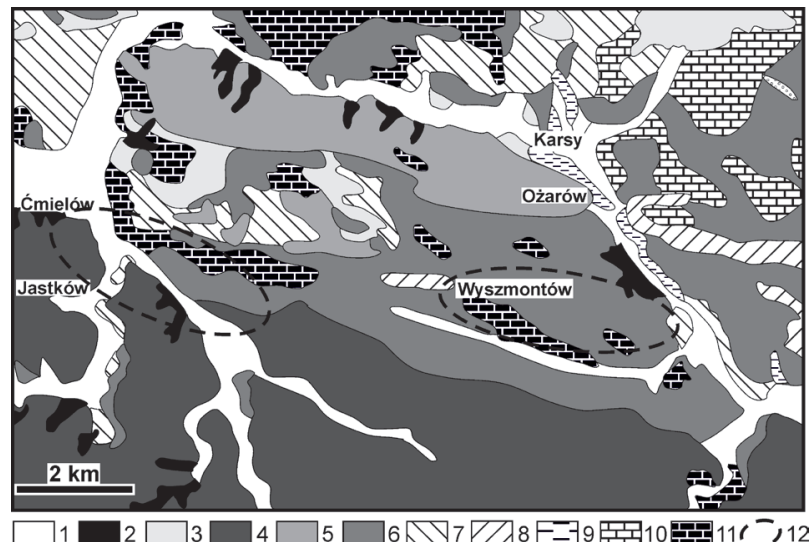

Fig. 3. Surface sediments in the marginal zone of the Sandomierz Upland between Ożarów and Ćmielów (on the basis of Mapa Geologiczna Polski I:200.00o downloaded from https://geolog.pgi.gov.pl).

Legend: Holocene: I - river sands and silts, 2 - colluvial sediments; Vistulian: 3 - cover sands, 4 - loess, 5-sandy loess; Saalian: 6 - glacial tills, 7 - fluvioglacial sands and gravels, 8 - kame sands, 9 - lacustrine silty sands; Cretaceous: Io - limestones and opokas (silaceous limestones); Jurassic: II - limestones; I2 - microregions of settlement of the Danubian communities.
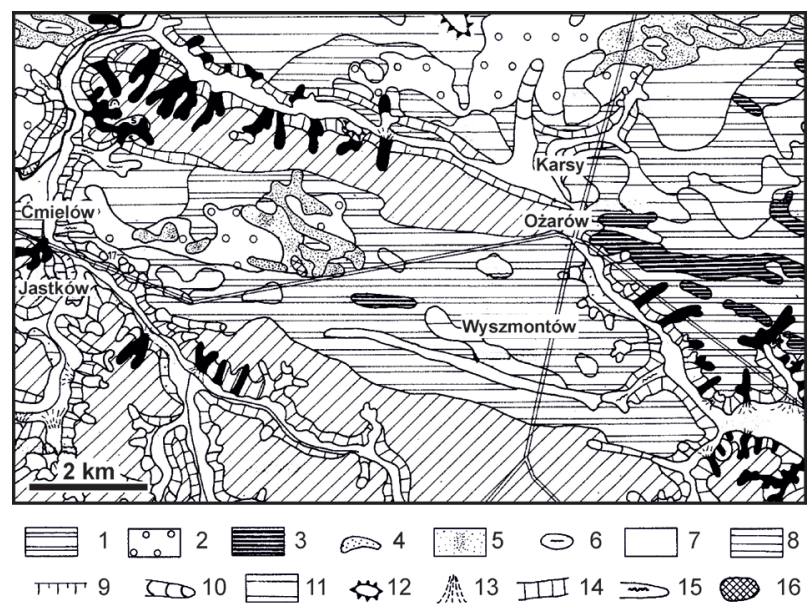

Fig. 4. Geomorphologic map of the marginal zone of the Sandomierz Upland between Ożarów and Ćmielów (after Złonkiewicz I998 with modifications). Symbols: I - glacial plain, 2 - fluvioglacial plain, 3 - kemes, 4 -dunes, 5-sand cover, 6 - deflation depressions, 7 - floor of river valley, 8 - accumulation terrace, 9 - terrace edge, Io - channelled valley, II - fragments of Tertiary erosion surfaces, I2 - surfaces of the pedestal, I3 - alluvial fan, I4 - erosional-accumulation edge, I5 - karstic valley, I6 - anthropogenic embankment. 


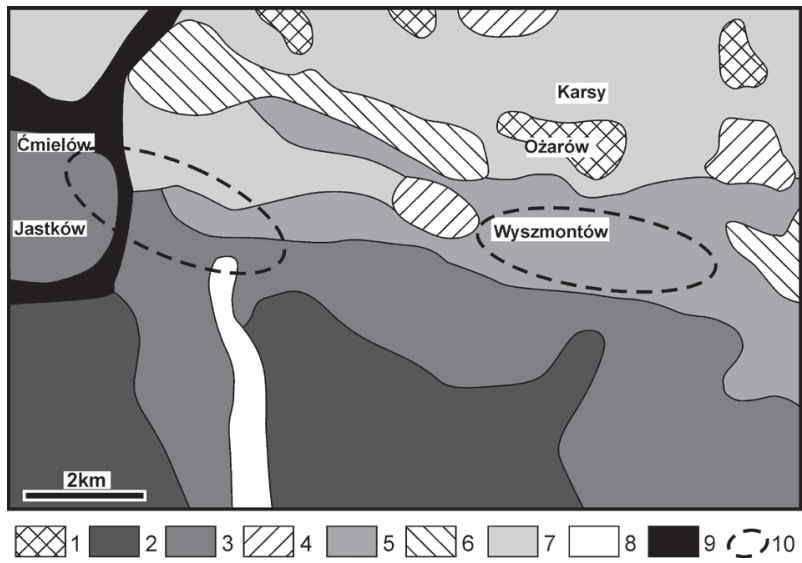

Fig. 5. Soil cover in the marginal zone of the Sandomierz Upland between Ożarów and Ćmielów (on the basis of Mapy gleb Polski 196I, simplified and modified). Symbols: I - rendzinas developed on Jurassic and Cretaceous carbonate rocks; 2 - chernozems developed on loess; 3 - complex of Cambisols and Luvisols developed on loess and loess-like deposits; 4-Luvisols developed on glacial tills and weathered clays; 5 - Luvisols developed on aquatic silts; 6 - Luvisols developed on loess and loess-like deposits; 7 - rusty soils and podzolic soils in place underlain with carbonate rocks made of weak loamy sands and loamy sands; 8 - muddy soils, peat and ground and gleyic soils; 9 - Fluvial soils (silty, loamy and clay); Io - microregions of settlement of the Danubian communities.

truncated Luvisols) derived from loess and loess-like sediments (Fig. 5). The northern part is characterized by a much more diversified, mosaic structure, covering the good loess soils derived from aquatic silts in the region of the edge of the loess plateau, which extends further north into low-fertility rusty and podzol soils derived from sandy sediments. The alluvial soils commonly documented in the bottoms of river valleys are relatively young soils (Fig. 5). The location of the discovered remains of settlement strongly correlates with this differentiation, showing their clear concentration in the area of good (western microregion) and medium good soils (eastern microregion) in terms of agricultural usefulness (Fig. 5). The distribution of individual sites in a zone dominated by rusty and podzol soils poor in nutrients for plants (Wojciechówka 2) indirectly indicates their non-agricultural character. This corresponds to the seasonal activity of human groups postulated for them, including with the exploitation of flint deposits there.

\section{Potential natural vegetation}

Geological and geomorphological factors as well as soil types would directly affect habitat types of potential natural vegetation (Matuszkiewicz 2007). For the studied area, the potential natural vegetation consists mainly of two basic forest communities; 


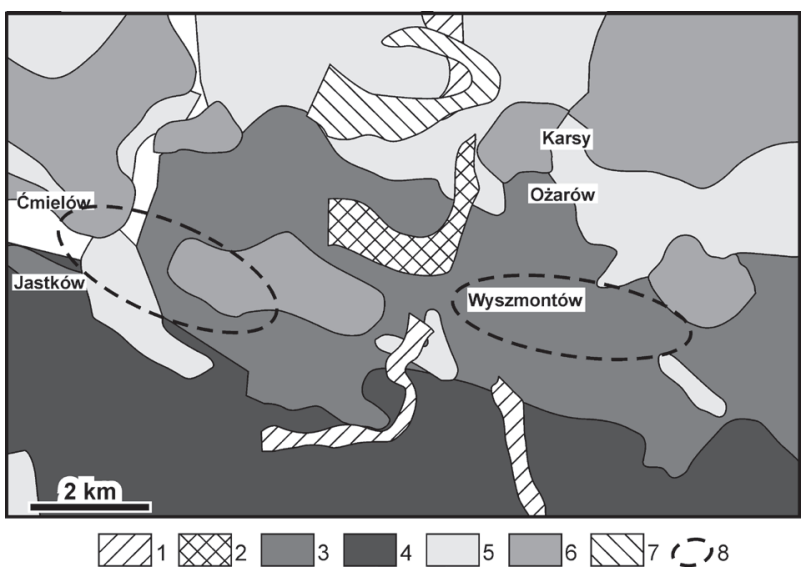

Fig. 6. Natural plant cover in the marginal zone of the Sandomierz Upland near Ożarów and Ćmielów (on the basis of Matuszkiewicz 2007). Legend: I - Ficario-Ulmetum chrysospl., 2 - Fraxino-Alnetum (Circaeo-Alnetum), 3 - Tilio-Carpinetum (Litt. Pol., poor), 4 -Tilio-Carpinetum

(Litt.-Pol., rich), 5 - Potentillo albae-Quercetum typicum, 6 - Querco-Pinetum, 7 - Festucetalia valesiacae; 8 - microregions of settlement of the Danubian communities

the southern part would have been dominated by the oak-hornbeam forest (TilioCarpinetum association) and the northern one would have supported a dry-ground oak dominated forest habitat (Potentillo albae-Quercetum typicum association). The area of the Sandomierz loess patch would have been occupied by an oak-hornbeam (TilioCarpinetum typicum) vegetation type, which is a broad-leaved deciduous forest growing in fresh habitat. The forest was relatively wet with the dominance of pedunculate oak Quercus robur and common hornbeam Carpinus betulus, with a small amount of European beech Fagus sylvatica, small-leaved lime Tilia cordata, common spruce Picea abies and silver fir Abies alba (Fig. 6). In turn, for the northern sandy part, typical habitats would have been oak-dominated communities (Potentillo albae-Quercetum typicum), constituting forests in the habitat type of a mixed forest with the dominance of sessile oak Quercus petrea and a constant natural admixture of Scots pine Pinus sylvestris in the forest composition. In addition, in the northern part the mixed forests of Querco roboris-Pinetum would have potentially been found, and thus the natural forest communities would have had a dominance of common oak and pine. Azonal plant habitats are associated with river valleys (Kamienna and Przepaść rivers and Wyszmontów Stream ). These are assigned to the communities of moist forests associated with fertile and hydrated habitats, i.e. Ficario-Ulmetum and Fraxino-Alnetum types. The first mentioned is an ash and elm riparian forest, and the second one an ash and alder forest (Fig. 6). In both types of communities, pedunculate oak would 
224 Marcin Szeliga, Radostaw Dobrowolski, Przemystaw Mroczek, Jacek Chodorowski ...

have been present in the admixture. With reference to the discovered remains of the settlements of early farming communities (Fig. IC), their occurrence can be assumed to have lain in places potentially occupied by forest communities with a significant share of oak, mainly growing in mixed oak and pine woodland in habitats outside river valleys and at the intersection of these communities with riparian forests and it can be assumed that they mainly exploited such areas.

\section{Archaeobotanical data}

Archaeobotanical studies on the samples obtained during the excavations in Tominy 6 included the analysis of macroscopic plant remains extracted during wet sieving of collected soil samples, imprints preserved in fired daub and ceramics, as well as charred wood. In the soil samples, mainly fruits and seeds have been preserved, some of which were uncharred. Remains of the last type were not included in the interpretation, because - according to assumptions adopted in archeobotany - such specimens, found in the dry deposit, are not related to the archaeological context (Lityńska-Zając and Wasylikowa 2005: 50-5I).

In the examined material, mainly the remains of primordial hulled wheat have preserved: emmer Triticum dioccon and einkorn T. monococcum. These were the caryopses and parts of the schaff, such as spikelets, basal parts of spikelets, so called "spikelet fork" and glumes, relatively abundant in the clay, both in the form of imprints, as well as burnt and highly dried fragments of tissues embedded in the clay. On this basis, it can be assumed that the crops of the LBK population were dominated by emmer and einkorn wheats. The local nature of the crops is confirmed by single diaspores of field weeds (e.g. rye brome Bromus secalinus), preserved in the studied material. Quantitative analyses indicate the more frequent occurrence of Triticum dioccon residues, which suggests the greater economic importance of this species. Previous archaeobotanical data confirm that both types of hulled wheat were an important cereal for the LBK communities in various regions of present-day Poland (i. a. Gluza 1994; Bieniek 2007; Lityńska-Zając 2007; Lityńska-Zając et al. 20I4; Lityńska-Zając et al. 2017). They could be sown separately or in the form of a mixture, in which the emmer wheat probably played the dominant role. Their joint growth in one field was possible because they are characterized by similar biological properties, such as sowing time, the date of emergence and harvest, and the length of the growing season, as well as the edaphic requirements. In Russia, such mixtures were sown even in the 2oth century (Januševič 1976: 44). It can not be ruled out that the einkorn may have appeared as a weed in a field of emmer. It is a persistent weed because - due to the greater brittleness of the ear - it can sprinkle spikelets before harvest from the field and thus caryopses itself (Gluza 1994).

Possibly, the grains of wheat were ground into flour or pounded for groats. It is a well-absorbed food, because it contains a lot of carbohydrates, mainly in the form of 
starch, as well as much smaller amounts of protein and fat (Domańska et al. 1982: 255). The einkorn flour has special properties: it has high nutritional values and, in comparison with other wheat species, it contains more protein and gluten. It is characterized by intense yellow colour, due to the high content of $\beta$-carotene (Mielke and Rodemann 2007). It is very likely, that the straw was also used, for instance to cover roofs, or as a bedding for farm animals (Lityńska-Zając and Wasylikowa 2005: 69, 77). The presence of cereal remains and cereal straw fragments in the daub and ceramics clearly confirms the intentional addition of threshing residue to the clay, which was also observed at other sites from the early Neolithic period (e.g. Moskal-del Hoyo et al. 2017, further literature there).

\section{Archaeozoological data}

A total number of 767 poorly preserved bone remains from site Tominy 6 were analysed (Makowiecki 20I8). The species and anatomical affiliation was specified only for $22.2 \%$ of specimens. They belong mainly to domestic (about $46 \%$ ) and wild (52\%) mammals. The last group also includes a horse. The remaining, inconsiderable percentage comprises fish remains (pike), reptiles (European pond turtle) and birds (I unidentified specimen). Among the wild mammals, apart from the horse, almost the same number of deer remains were recorded. Only a few remains belong to the deer, moose, fox, bear and badger. There were also some remains of aurochs or a very large cattle variety, as well as wolf or a very large dog. Among the domestic mammals the most numerous are cattle and small ruminants, i.e. sheep/goat, with much smaller percentage of pigs.

The diverse structure of the fauna from Tominy results from the combined method of obtaining raw materials of animal origin. This consisted, on the one hand, of the breeding of domestic mammals as part of the culturally-determined form of agriculture, and on the other, the important role of hunting, mainly for horses. According to the current state of knowledge (Benecke 2006), it should be assumed that the remains of hunted animals originated from free-living (wild) populations. The range of fauna, due to habitat preferences belonging to different groups (Makowiecki 2008, there further literature), indicates the exploitation of diverse landscape zones by the settlers, both forest areas (deer, badger and bear), as well as open, grassy habitats (horse). The latter habitats were also suitable for grazing domesticated herbivorous ruminants. The presence of moose indicates the hunting penetration of forest, wetland and swampy areas, possibly located in the valley of Vistula or smaller, closer streams, i.e. Czyżówka River or Wyszmontów Stream. Presumably, in small watercourses of this type, as well as in eutrophicated river pools, pikes and mud turtles were caught. The latter species was one of the most important components of the diet among the peoples of Atlantic optimum cultures (Makowiecki and Rybczyński 20oI). Fishing and turtle hunting were particularly important in spring and in early summer, when the stocks 
226 Marcin Szeliga, Radostaw Dobrowolski, Przemystaw Mroczek, Jacek Chodorowski ...

of agricultural products were depleted, and animals of these species gather into herds for reproductive reasons (Makowiecki 2003).

\section{DISCUSSION AND CONCLUSIONS}

The results of the conducted research confirm an intense and permanent nature of the settlement at the intersection of the Sandomierz Upland and Iłża Foothills, throughout the period of development of groups cultivating the Danubian cultural traditions. From this small borderland, currently 49 sites are known (Fig. IC) that document the settlement activity of culturally diverse early-agricultural communities, at least from the late 6th to the beginning of the 4 th millennia BC. They mark the northernmost range of the dense Danubian groups settlement, broadly understood as the "Sandomierz ecumene of settlement", at the same time clustering within at least two basic settlement microregions, located at the intersection of loess patch and sandyclay formations (Ćmielów-Wólka Wojnowska) and entirely beyond the loess cover (Tominy-Wyszmontów). Their location seems to indicate a much higher settlement intensity at the borderline of both mesoregions, than in the entire northern part of the Sandomierz Upland (Fig. IC and 2A-B). However, it should be emphasized that this picture may be accidental and result only from the different intensity of archaeological research, carried out so far in both these areas.

Despite its preliminary nature, the obtained information enables a general reconstruction of the colonization on the edge of the Sandomierz Upland and its northern foreland, and to attempt a provisional assessment of the intensity of these processes over the 6 th and 5 th millennia BC. The initial phase was marked by the emergence (at least in the last quarter of the 6th millennium BC) of the LBK community, which established several settlements along the Wyszmontów Stream (Tominy 6 and I2) and the lower courses of Krzczonowianka and Przepaść rivers (Ćmielów 2, Jastków 46, Wólka Wojnowska 33). These were large and permanent settlements that functioned even for about 200-300 years, as indicated by the radiocarbon dates from site 6 in Tominy (Szeliga 20I7). They initiated the development of the local settlement network, continued almost unchanged by post-linear communities throughout the 5 th millennium BC. This is indicated, among other things, by the widespread presence of remains of MLC settlements, recorded within the earlier LBK settlement sites (MichalakŚcibior 1994; Szeliga and Zakościelna 2007: I4; Kadrow and Olejarczyk 20I0: 136). The range of the stylistic diversity on the MLC ceramics (Ib and Ic phases) discovered on these sites allows indirect assumption of a longer settlement period than in the case of LBK of both microregions by communities of this culture, within the range of 4800-4200 BC (see Kadrow and Zakościelna 2000: Fig. 45). The youngest period of the Danubian settlement in these areas was connected with the appearance of the 


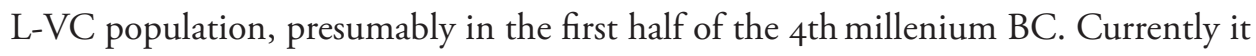
is the least-known episode of Danubian settlement, documented by diagnostic artefacts discovered mainly outside features, and only sporadically (Tominy 6 and I2) by a few immobile features (Szeliga and Zakościelna 2007: I4; Kadrow and Olejarczyk 20IO: 136). Although this situation indicates the continuation of settlement processes in the discussed areas during the $\mathrm{L}-\mathrm{VC}$ development period, this hampers the unambiguous assessment of its actual intensity and length of continuance within both microregions. The nature of previous findings and the distribution of L-VC sites (Fig. 2A-B) may indicate a diminution of settlement in relation to earlier periods and shifting its main concentration to the loess hills of the northern Sandomierz Upland.

Regardless of the chronological and cultural affiliation of particular findings and sites, the location of both regions of site concentration allows us to state that the range of dense settlement of Danubian groups during their whole development period did not extend beyond the closest vicinity of a continuous loess cover (maximum I.5-2 km), revealing close connection to the location and course of currently small watercourses, i.e. the Wyszmontów Stream in the east and the Przepaść and Krzczonowianka rivers - in the west. It seems that they were the key factor enabling the colonization of the zone of the Sandomierz Upland northern foreland outside the loessic regions, also determining the maximum range of successive periods of permanent settlement of Danubian communities. These streams constituted natural sources of water and food, and the bottom parts of their valleys could also have served as arteries for communication, used, among others, for economic purposes, including excursions to the natural resources outcrops. This is indicated by the data from the LBK settlement in Tominy, where the basic production raw material was Świeciechów flint, imported from outcrops located on the right bank of the Vistula (Szeliga 2008: Fig. I2).

A very important factor, stimulating the settlement processes of early-agricultural communities, was also access to suitably fertile soils (see Kruk 1971: 275-279; 1973: I44-I46). In the case of the analysed area, this dependence is marked on the macro-regional level, revealing a clear correlation of the extent of permanent settlement with the zone of occurence of good and medium quality soils (Fig. 4). The distribution of sites within both microregions, however, does not reveal such a close correlation with the functional values of the local soil cover, comprising on the one hand - the areas covered with fertile soils formed on loess cover (western microregion), and on the other hand - with slightly less efficient, moderately good loessic soils (eastern microregion). This allows us to recognize the soil conditions prevailing in the settlement zone as undoubtedly significant indicator of the preferences of local early agricultural communities, nevertheless rather secondary to the hydrographic conditions.

Culminations and gentle slopes of small hills, located along the mentioned watercourses, were particularly preferred as the location of settlements, from the oldest phase of the Neolithic colonization of these areas, without revealing significant differences 
also during the development of subsequent post-linear communities (Fig. 2A-B and 3). The location of settlements at the intersection of oak-pine and riverine forests enabled the exploitation of diversified environmental resources, both in the field of agriculture and breeding, as well as gathering and hunting. This is clearly confirmed in the archaeozoological material from Tominy, indicating, in addition to the importance of breeding, the very important role of hunting, conducted at the same time in various forest and treeless areas near the settlement. Penetration and agricultural exploitation of oak-pine and riverine forests areas are also confirmed by the archaeobotanical data, including both the diaspores of field weeds, as well as the taxonomically heterogeneous wood charcoals. The setting up of arable fields required the deforestation of at least a small area, through stubbing or burning. Light soils, easy to work, well lit and provided with water and nutrients were convenient for growing cereals (emmer and einkorn wheats).

The obtained results significantly complement and verify current knowledge about the scale and range of the settlements of the Danubian communities within the region of the Sandomierz settlement ecumene. They document the previously poorly known process of formation and functioning of the early Neolithic settlement clusters in the areas situated on the edges of the uplands, especially outside the range of compact loess cover, i.e. within the ecological-landscape zones that differ from the basic settlement preferences of early-agricultural communities (Sielmann I97I: II9-I30; Kruk I973: 72-76; Czekaj-Zastawny 2008: 98-104). The number and cultural diversity of the settlement relics discovered in the Wyszmontów Stream valley confirms the permanent and dynamic nature of this colonization of this region throughout the 6th and 5 th millennia $\mathrm{BC}$, revealing the significant position of this type area in the entire settlement system of the Danubian groups. The convenient, though specific, natural conditions of such areas and high adaptation abilities of the early-agricultural groups allow us to assume the existence of similar settlement concentrations, also in other areas on the borderland of loess uplands in the upper and middle Vistula basin. This can be confirmed by, among other things, the recent discoveries in the zone of the southern edge of the Vistula valley near Cracow (Zastawny 20I4).

\section{ACKNOWLEDGEMENTS}

The research and analysis were funded by the National Science Centre in Poland (OPUS Iо; UMO-2015/19/B/HS3/or720). 


\section{REFERENCES}

Balcer, B. and Kowalski, K. 1978. Z badań nad krzemieniem pasiastym w pradziejach. Wiadomości Archeologiczne 43: 127-I45.

Benecke, N. 2006. Late prehistoric exploitation of horses in central Germany and neighboring areas - the archaeozoological record. In S. L. Olsen, S. Grant, A. Choyke and L. Bartosiewicz (eds), Horses and Humans: the evolution of the human-equine relationship, 195-208. Oxford. British Archaeological Report IS 1560.

Bieniek, A. 2007. Neolithic plant husbandry in the Kujawy region of central Poland. In S. Collegde and J. Conolly (eds), The Origins and Spread of Domestic Plants in Southwest Asia and Europe, 327-342. California.

Budziszewski, J. 199I. W sprawie badań AZP na arkuszu 84-72. In J. Gurba (ed.), Sprawozdania z badań terenowych Katedry Archeologii UMCS w I99I roku, 58-6I. Lublin.

Czekaj-Zastawny, A. 2008. Osadnictwo spoteczności kultury ceramiki wstegowej rytej w dorzeczu górnej Wisty. Kraków.

Domańska, H., Droese, H., Gawrońska-Kulesza, A., Kowalski, S., Roszak, S., Śmierzchalski, L. and Trzecki, S. 1982. Ogólna uprawa roli i roślin. Warszawa.

Gluza, I. 1994. Wstępne wyniki badań odcisków roślinnych ze stanowisk kultury ceramiki wstęgowej rytej w Gniechowicach i Starym Zamku, woj. wrocławskie. In K. Wasylikowa (ed.), Warsztaty Archeobotaniczne, Polish Botanical Studies, Guide book Series II: 55-69.

Januschevich, Z. V. 1976. Kulturnye rastenija jugo-zapada SSSR po paleoetnobotanicheskim issledovanijam. Kischinev.

Kadrow, S. and Olejarczyk, P. 20Io. "Cord” ornaments on Funnel Beaker Culture pottery at Tominy, site I2. In A. Kośko (ed.), "Cord" Ornaments on Pottery in the Vistula and Dnieper Interfluvial Region: sth-4th Mill. BC, 135-I45. Poznań. Baltic-Pontic Studies I5.

Kadrow, S. and Zakościelna, A. 2000. An Outline of the Evolution of Danubian cultures in Małopolska and western Ukraine. In A. Kośko (ed.), The Western Border Area of the Tripolye Culture, 187-255. Poznań. Baltic-Pontic Studies 9.

Končelová, M. 20I2. The settlement structure of the Linear Pottery Culture in East Bohemia - geographical patterns and cultural continuity, In F. Kreienbrink, M. Cladders, H. Stäuble, T. Tischendorf and S. Wolfram (eds), Beitäge der internationalen Tagung "Neue Fragen zur Bandkeramik oder alles beim Alten?!”, 190-197. Dresden. Arbeits- und Forschungberichte zur sächsischen Bodendenkmalpflege 25.

Kondracki, J. 2002. Geografia regionalna Polski. Warszawa.

Koster, A. E. 1988. Ancient and modern cold-climate aeolian sand deposition: a review. Journal of Quaternary Science 3: 69-83.

Kowalewska-Marszałek, H. 2002. Krzemień świeciechowski w neolicie Wyżyny Sandomierskiej. Kilka uwag na temat rozprzestrzenienia inwentarzy. In B. Matraszek and S. Sałaciński (eds), Krzemień świeciechowski w pradziejach, 177-207. Warszawa. Studia nad Gospodarką Surowcami Krzemiennymi w Pradziejach 4.

Kowalewska-Marszałek, H. 2008. Krzemień czekoladowy w neolicie Wyżyny Sandomierskiej. Uwagi na temat rozprzestrzenienia inwentarzy. In W. Borkowski, J. Libera, B. Sałacińska and S. Sałaciński (eds), Krzemień czekoladowy w pradziejach, 245-276. Waszawa-Lublin. Studia nad Gospodarką Surowcami Krzemiennymi w Pradziejach 7.

Kowalewska-Marszałek, H. 20I2. Linear Pottery and Lengyel settlement structures on the Sandomierz Upland (Little Poland) - continuity or change? In S. Wolfram and H. Stäuble (eds), Siedlungsstruktur und Kulturwandel in der Bandkeramik. Beiträge der internationalen Tagung Neue Fragen zur Bandkeramik oder alles beim Alten?!”, 284-294. Dresden. Arbeits- und Forschungsberichte zur sächsischen Bodendenkmalpflege, Beiheft 25. 
230 Marcin Szeliga, Radostaw Dobrowolski, Przemystaw Mroczek, Jacek Chodorowski ...

Kowalewska-Marszałek, H. (ed.) 20I7. Sandomierz-Wzgórze Zawichojskie - neolityczna osada obronna. Badania I98I-I989. Cz. I. Studia i materiaty. Warszawa.

Kruk, J. 1971. Próba rekonstrukcji naturalnych warunków rozwoju społeczeństw neolitycznych na obszarze lessów Niecki Nidziańskiej. Z metodyki badań archeologicznych. Sprawozdania Archeologiczne 23: 259-284.

Kruk, J. 1973. Studia osadnicze nad neolitem wyżyn lessowych. Wrocław-Warszawa-Kraków-Gdańsk.

Kruk, J., Milisauskas, S., Alexandrowicz, S. W. and Śnieszko, Z. 1996. Osadnictwo i zmiany środowiska naturalnego wyżyn lessowych. Studium archeologiczne i paleogeograficzne nad neolitem $w$ dorzeczu Nidzicy. Kraków.

Kulczycka-Leciejewiczowa, A. 2008. Samborzec. Studium przemian kultury ceramiki wstegowej rytej. Wrocław.

Libera, J. and Zakościelna, A. 1990. Badania powierzchniowe w południowej części Niecki MagońFolwarczyska. In. J. Gurba (ed.), Sprawozdania z badań terenowych Katedry Archeologii UMCS w I99o roku, 57-64. Lublin.

Lityńska-Zając, M. 2007. Early Neolithic agriculture in south Poland reconstructed from archaeobotanical plant remains. In S. Collegde and J. Conolly (eds), The Origins and Spread of Domestic Plants in Southwest Asia and Europe, 315-326. California.

Lityńska-Zając, M., Czekaj-Zastawny, A. and Rauba-Bukowska, A. 20I7. Utilization of cultivated and wild plants in the economy of the Linear Pottery Culture in the Upper Vistula basin. Sprawozdania Archeologiczne 69: 233-257.

Lityńska-Zając, M. and Wasylikowa, K. 2005. Przewodnik do badań archeobotanicznych. In J. B. Faliński (ed. of series), Vademecum Geobotanicum. Poznań.

Lityńska-Zając, M., Wasylikowa, K., Cywa, K., Tomczyńska, Z., Madeyska, M., Koziarska, A. and Skawińska-Wieser, K. 20I4. Brzezie, stan. I7, gm. Kłaj. Materiały archeobotaniczne z obiektów kultury ceramiki wstęgowej rytej. In A. Czekaj-Zastawny (ed.), Brzezie 17. Osada kultury ceramiki wstęgowej rytej, 405-436. Kraków.

Łanczont, M., Mroczek, P., Zieliński, P., Hołub, B., Kusiak, J., Bałaga, K., Komar, M., Łącka, B., Żogała, B. and Mendecki, M. 20I4. Regional palaeogeographic analysis of the site Wilczyce Io and Opatowka valley, and stratigraphic context of the ice wedge cast. In Schild R. (ed.), Wilczyce. A Late Magdalenian Winter Hunting Camp in Southern Poland, 3I-80. Warszawa.

Makowiecki, D. 2003. Historia ryb i rybotówstwa $w$ holocenie na Niżu Polskim w świetle badań archeoichtiologicznych. Poznań.

Makowiecki, D. 2008. Badania archeozoologiczne w studiach nad paleośrodowiskiem człowieka. In W. Chudziak (ed.), Człowiek i środowisko przyrodnicze we wczesnym średniowieczu w świetle badań interdyscyplinarnych, I23-137. Torun.

Makowiecki, D. 20I8. Analiza archeozoologiczna neolitycznych materiatów osteologicznych ze stanowiska $w$ Tominach, gmina Ożarów. Unpublished typescript stored in Institute of Archaeology Maria Curie-Skłodowska University in Lublin.

Makowiecki, D. and Rybacki, M. 20or. Archeologiczne znaleziska szczątków żółwia i jego znaczenie u społeczeństw prahistorycznych oraz wczesnohistorycznych na Niżu Polskim. In B. Najbar and S. Mitrus (eds), Żótw btotny, 97-102. Świebodzin.

Mapa Geologiczna Polski r:200,00o from https://geolog.pgi.gov.pl

Mapa gleb Polski w skali r:30o tys. Arkusz E 4 Kielce. IUNG. Puławy. Wydawnictwa Geologiczne. Warszawa 196r.

Maruszczak, H. 1954. Werteby obszarów lessowych Wyżyny Lubelskiej. Annales Universitatis Mariae Curie-Sklodowska, sectio B - Geographia, Geologia, Mineralogia et Petrographia 8: 123-I37.

Maruszczak, H. 196I. Le relief des terrains de loess sur le Plateau de Lublin. Annales Universitatis Mariae Curie-Sklodowska, sectio B - Geographia, Geologia, Mineralogia et Petrographia I5: 93-I22. 
Matuszkiewicz, J. M. 2007. Zespoty leśne Polski. Warszawa.

Matyaszewski, M. 2017. Sprawozdanie z ratowniczych badań archeologicznych stanowiska nr 33 Wólce Wojnowskiej (AZP 85-7I/248), gm. Ćmielów, pow. ostrowiecki, woj. świętokrzyskie, wykonywanych w 2017 roku w związku z budowa obwodnicy Ćmielowa. Unpublished typescript stored in Regional Historical Monuments Conservation Office in Sandomierz.

Michalak-Ścibior, J. 1992. Nowe znaleziska obsydianu na Wyżynie Sandomierskiej. Acta Archaeologica Carpathica 3I: 35-53.

Michalak-Ścibior, J. 1994. Nowe źródła do znajomości klasycznej fazy kultury malickiej z Wyżyny Sandomierskiej (stanowisko 2 w Ćmielowie). Sprawozdania Archeologiczne 46: 3I-8I.

Michalak-Ścibior, J. and Taras, H. 1995. Wczesnoneolityczna osada w Sandomierzu Krukowie, stan. 20. Sprawozdania Archeologiczne 47: 69-I35.

Mielke, H. and Rodermann, B. 2007. Zum Anbau und Pflanzenschutz bei der seltenen Weizenart Einkorn (Triticum monococcum). Nachrichtenblatt des Deutschen Pflanzenschutzdienstes 59(7): 162-165.

Modderman, P. J. R. 1959. Die geographische Lage der bandkeramischen Siedlungen in den Niederlanden. Palaeohistoria 6-7: I-6.

Moskal-del Hoyo, M., Rauba-Bukowska, A., Lityńska-Zając, M., Mueller-Bieniek, A. and CzekajZastawny, A. 2017. Plant materials used as temper in the oldest Neolithic pottery from southeasern Poland. Vegetation History and Archaeobotany 26: 329-244.

Mroczek, P. 2007. Pokrywy lessowe regionu sandomierskiego i świętokrzyskiego. In A. Zieliński (ed.), Przeobrażenia środowiska geograficznego w potudniowo-wschodniej części regionu świętokrzyskiego, 53-62. Kielce.

Podkowińska, Z. 1952. Prace wykopaliskowe na stanowisku „Gawroniec-Pałyga” w Ćmielowie, w pow. opatowskim 1950 r. Wiadomości Archeologiczne I8: 20I-242.

Podkowińska, Z. 1959. Osada neolityczna kultury starszej ceramiki wstęgowej (rytej) w Jurkowicach, pow. opatowski (Z zagadnień gospodarki plemion kultury starszej ceramiki wstęgowej w Polsce). Archeologia Polski 3: 7-50.

Sielmann, B. 197I. Der Einfluss der Umwelt auf die neolithische Besiedlung Südwestdeutschlands unter besonderer Berücksichtigung der Verhältnisse am nordlichen Oberrhein. Acta Praehistorica et Archaeologica 2: 65-197.

Szeliga, M. 2008. Kontynuacja badań wykopaliskowych na wielokulturowym stanowisku $6 \mathrm{w}$ Tominach, pow. opatowski, w latach 2006-2007. Archeologia Polski Środkowowschodniej I0: 9-27.

Szeliga, M. 2017. The First Chronometric Markings of the Late Stage of the LPC in the Northern Foreland of the Sandomierz Upland. Analecta Archaeologica Ressoviensia I2: 43I-447.

Szeliga, M., Dobrowolski, R., Chodorowski, J., Pidek, I. A. and Mroczek, P. 2or8. Zapis geoarcheologiczny działalności człowieka w neoholocenie w południowo-wschodniej części Przedgórza Iłżeckiego (centralna Polska). Acta Geographica Lodziensia 107: 155-173.

Szeliga, M. and Zakościelna, A. 2007. Wstępne sprawozdanie z ratowniczych badań wykopaliskowych na wielokulturowym stanowisku 6 w Tominach, pow. opatowski, w 2006 roku. Archeologia Polski Środkowowschodniej 9: 9-23.

Więckowska, H. 1971. Materiały krzemienne i kamienne z osad kultury ceramiki wstęgowej i trzcinieckiej w Opatowie. In. W. Chmielewski (ed.), Z polskich badań nad epoka kamienia, IO3-I83. Wrocław-Warszawa-Kraków-Gdańsk.

Zastawny, A. 20I4. Neolityczne osadnictwo strefy „piaskowej” południowego obrzeżenia doliny Wisły pod Krakowem w świetle badań na st. I3 w Kokotowie, gm. Wieliczka, woj. małopolskie. Raport 9: II-52.

Złonkiewicz, Z. 1998. Szczegótowa Mapa Geologiczna Polski w skali i:5o ooo. Arkusz Ożarów (819). Warszawa. 
